DOI: 10.5604/01.3001.0012.0713

\title{
ANALYSIS OF THE EFFECTIVENESS OF SELECTED SEGMENTATION METHODS OF ANATOMICAL BRAIN STRUCTURES
}

\author{
Róża Dzierżak, Magdalena Michalska \\ Lublin University of Technology, Institute of Electronics and Information Technologies
}

Abstract. An important aspect of analysis medical images is acknowledging the role of the segmentation process of individual anatomical structures. This process allows to show the most important diagnostic details. Owing to the segmentation the areas of interest (ROI) it is possible to adapt the methods of further image analysis considering the specification of selected elements. This process has been widely used in medical diagnostics. The article presents the use of segmentation by thresholding, segmentation by region growth and by edge detection to extract the parts of the human brain the user is interested in. The series of MRI (magnetic resonance imaging) images were used. The aim of the research was to develop the methods that would allow comparing the effectiveness various types of anatomical brain structures' segmentation in two dimensions. The above methods present the different impact that selected types of segmentation, masks or parameters have on the most accurate depiction of a selected human brain element.

Keywords: brain imaging, image segmentation, magnetic resonance imaging

\section{ANALIZA SKUTECZNOŚCI WYBRANYCH METOD SEGMENTACJI STRUKTUR ANATOMICZNYCH MÓZGU}

Streszczenie. Istotnym aspektem analizy obrazów medycznych jest dostrzė̇enie roli procesu segmentacji poszczególnych struktur anatomicznych. Proces ten pozwala na ukazanie najistotniejszych pod wzgledem diagnostycznym szczegółów. Dzięki segmentacji obszarów zainteresowania (ROI) możliwe jest odpowiednie dostosowanie metod dalszej analizy obrazów uwzględniając specyfikę wybranych elementów. Proces ten znalazł rozległe zastosowanie $w$ diagnostyce medycznej. W artykule przedstawiono wykorzystanie segmentacji przez progowanie, przez rozrost regionów oraz przez wykrywanie krawędzi, w celu wyodrębnienia interesujących użytkownika części ludzkiego mózgu. Wykorzystano serie obrazów MRI (rezonans magnetyczny). Celem badań byto opracowanie metod, które pozwola porównać skuteczność różnych typów segmentacji struktur anatomicznych mózgu w dwóch wymiarach. Zaprezentowane metody pokazuja różny wplyw wybranych rodzajów segmentacji, masek czy parametrów na dokładniejsze ukazanie poszczególnych elementów ludzkiego mózgu.

Słowa kluczowe: obrazowanie mózgu, segmentacja obrazu, rezonans magnetyczny

\section{Introduction}

Medical imaging is currently one of the most dynamically developing issues in biomedical engineering. Owing to the use of technical and IT solutions, the correct assessment of patients' condition is better than ever. Various imaging diagnostics techniques allow method to be adapted to character of the examined objects $[1,5,12]$.

The tests allow patient's body image to be obtained along with the characteristics of his internal organs. The test results usually involve more structures than are evaluated. Therefore, it is necessary to isolate the area of interest in order to adapt further methods of image analysis appropriate to the studied area $[1,11]$.

Segmentation is a process aimed at extracting from the results the elements that are to be further analyzed. The processing of medical images makes it necessary to distinguish the tested object from the rest of the less important details of the image. All elements that do not belong to ROI (Region of Interest) can be included in the background $[8,11,12]$.

Currently used medical imaging techniques allow to obtain an image on which tissues have similar properties [14]. This creates a problem regarding the precise separation of the examined structures from other elements. In order for the obtained results to have a diagnostic value, the isolated objects must be in accordance with the actual interpretation of the medical image $[3,9]$.

The scope of the article is the analysis of the effectiveness of the three segmentation types. The adopted measure of effectiveness is the operator's ability to distinguish between the anatomical structures of the brain, complexity of the selected segmentation algorithm and calculation effort.

\section{Methods}

The selecting of the particular segmentation technique should begin by considering the nature of the diagnostic problem and image origin $[9,11]$. In the initial stages of the research on the segmentation process, the main method was to perform image binarization. It was performed by thresholding, which allowed to distinguish the examined object and background $[7,9]$.

\subsection{Segmentation based on thresholding}

Segmentation by thresholding is the most popular and the most commonly used method of extracting objects from an image. The most important part of the process is to determine the threshold value $\mathrm{T}$ in the image brightness scale. The calculated value divides pixels into two groups: image points $f(x, y) \geq T$ and background points $f(x, y)<T$. The result of this operation is to obtain a binary image [8].

Threshold values can be determined based on the entire image (this is the so-called global brightness threshold), or depending on spatial coordinates $(\mathrm{x}, \mathrm{y})$ (the so-called dynamic brightness threshold). The threshold may also depend on a certain image feature such as average brightness in a certain environment. The determined value is then called the local brightness threshold [10].

For segmentation by thresholding, a matrix representing the input image is used, a matrix representing the threshold result (int) containing positions of pixels greater than a given threshold [13].

\subsection{Segmentation by region growth}

The region segmentation algorithm checks the neighboring pixel grains and decides on the basis of the assumed range if a given pixel should be added to the current region. The process runs iteratively, as in the data clustering algorithms.

The first step in creating the region is determining grains. They are determined on the basis of a previously specified criterion. The region grows from the grain to the adjacent pixel depending on the level of gray. These values are determined based on the histogram of the image.

During the initial stage of dividing the areas, the whole image is treated as one region. Then the uniformity of the region is checked. If the area does not meet the given criterion, it is divided into equal parts and the iterative step is terminated. In the next stage, all four regions are considered. If one of them does not meet the criterion of uniformity, it is automatically divided into four. This process is repeated until all areas meet the required criterion [2]. 
The correct grain selection is very important. Depending on the desired effect, the placement of grains in the same image can be different. The more data is known, the easier it is to choose grains and thresholds. An important issue is the scope, i.e. predetermined level, below which the algorithm assigns pixels to the common region [4]. Segmentation by the growth of regions gives the possibility to define the threshold and range, which allows specifying the particular parameters required to carry out the segmentation. The input parameters of the function used in Matlab are matrix representing a segmented image, parameter defining the location of starting points (grains) for the region's proliferation procedure and the value of threshold set by the user. When the difference between the value of image element and the grain exceeds threshold value, the region's growth in given direction is completed.

\subsection{Segmentation by edge detection}

Segmentation by edge detection determines threshold and mask that allow specifying the particular, parameters needed to perform the segmentation [6]. Implemented in masks are: Prewitt, Sobel, Roberts. The result of the function to segment the image using the edge algorithm is a matrix representing the image resulting from segmentation. It takes logical values 0 and 1 . The input parameters of function used are the matrix representing segmented image, the matrix of mask used and threshold value.

\section{Materials}

To analyze the segmentation methods, a series of $64 \mathrm{~T} 1$-size images of size $256 \times 256$ saved in the gray scale was used. Images were obtained by magnetic resonance imaging (MRI). Crosssections are made every $3 \mathrm{~mm}$. The GE Medical Systems $1.5 \mathrm{~T}$. was used to obtain image data. The times used are $\mathrm{TR}=35$, $\mathrm{TE}=5$. The results were recorded in the DICOM standard An important step in the segmentation algorithm is to create a histogram image, based on its analysis, the user decides on the chosen type of segmentation.

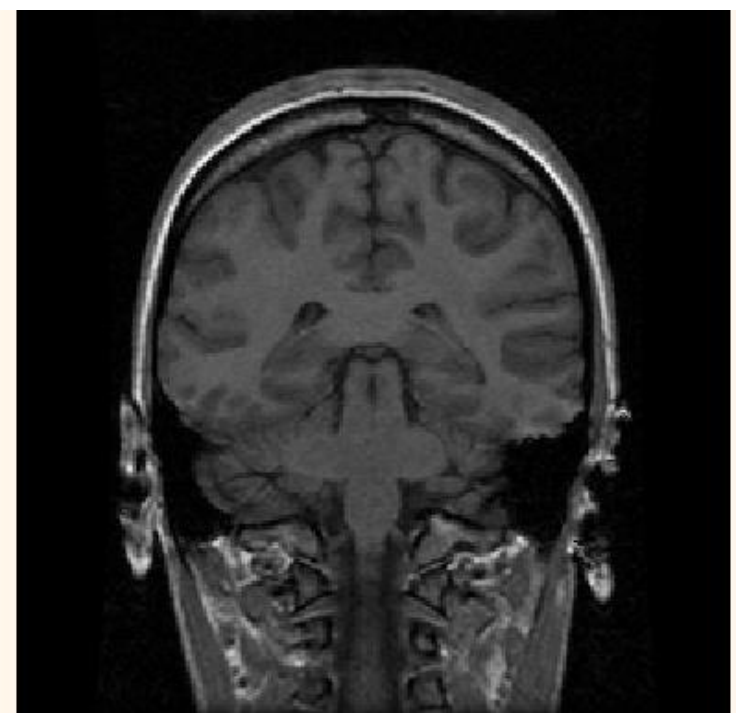

Fig. 1. Original MRI brain image

\section{Results}

The results of the experiments carried out are images created as a result of the segmentation by thresholding, the segmentation by edge detection and the segmentation by region growth. Each set of image data is represented by values from 0 to 255 (according to the MATLAB indexing method, the intensity values in this image take the values $1-256$ ). A black and white image is an $\mathrm{M} \times \mathrm{N}$ matrix containing only 0 and 1 . The images in the program are gray images representing its matrix size $\mathrm{M} \times \mathrm{N}$ with values from the set $[0,255]$, which corresponds to 256 shades of gray.

The first experiment was the segmentation by thresholding. In Figure 2 (a) we can see a significant area of the cerebellum and the initial segment of the spinal cord. As can be seen in the segmented images, the extended core has the shape of a cone with the base pointing upwards and it passes into the spinal cord. The limitations of the spinal cord are: the lower edge, the pyramid intersections and the starting point of the spinal cord of the first cervical spinal nerve pairs. The pons appears on the abdominal side of brain as a thick, wide band laterally outside the cerebral peduncles of brain. Its lateral parts penetrate the cerebellum as branches.
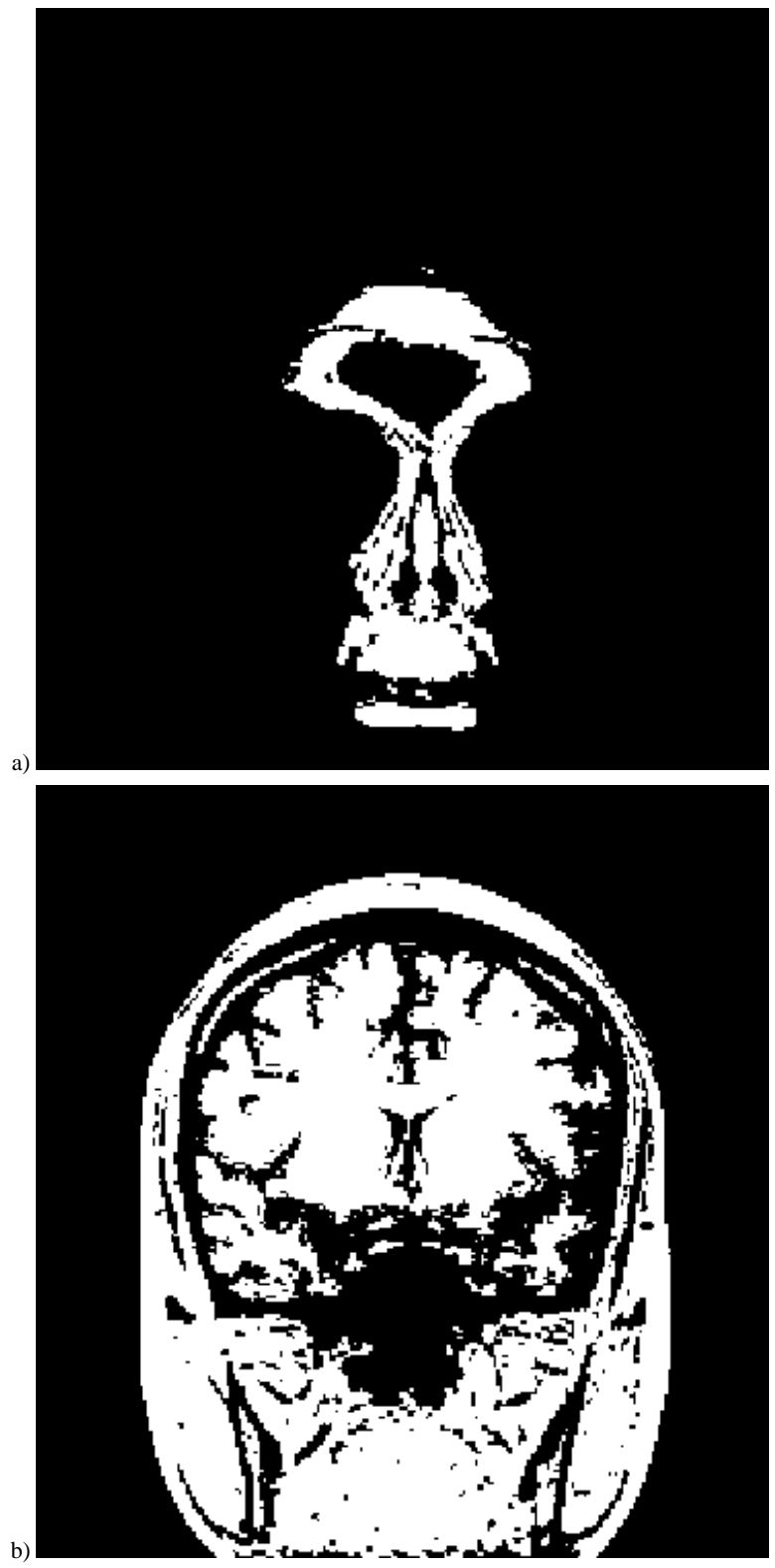

Fig. 2. Segmentation by thresholding images with preset thresholds: (a) 40, (b) 60

Figure 3 illustrates segmentation by edge detection. Despite the same value of the factor by which the pixels of image subjected to filtration are multiplied, each of the masks gives a different effect. The Sobel mask more clearly detected edges around the spinal cord, where there are many more areas of varying intensity than the Prewitt mask. Each of masks perfectly shows the outline of the skull, the boundaries between each of three meninges, the contour of white matter and soft tissues surrounding the skull. Determining the smaller parameter of selected mask gives better detection of each edge. The brains and spinal cord are covered with three meninges. The outer cover creates dura mater which consists of two plaques. Under the dura 
mater there is an arachnoid, which is separated from the dura mater by a slit. A pia mater lies under the arachnoid, which covers the surface of the cortex and the spinal cord. The pia mater and arachnoid are connected by delicate beams; between them, there are spaces filled with cerebrospinal fluid.
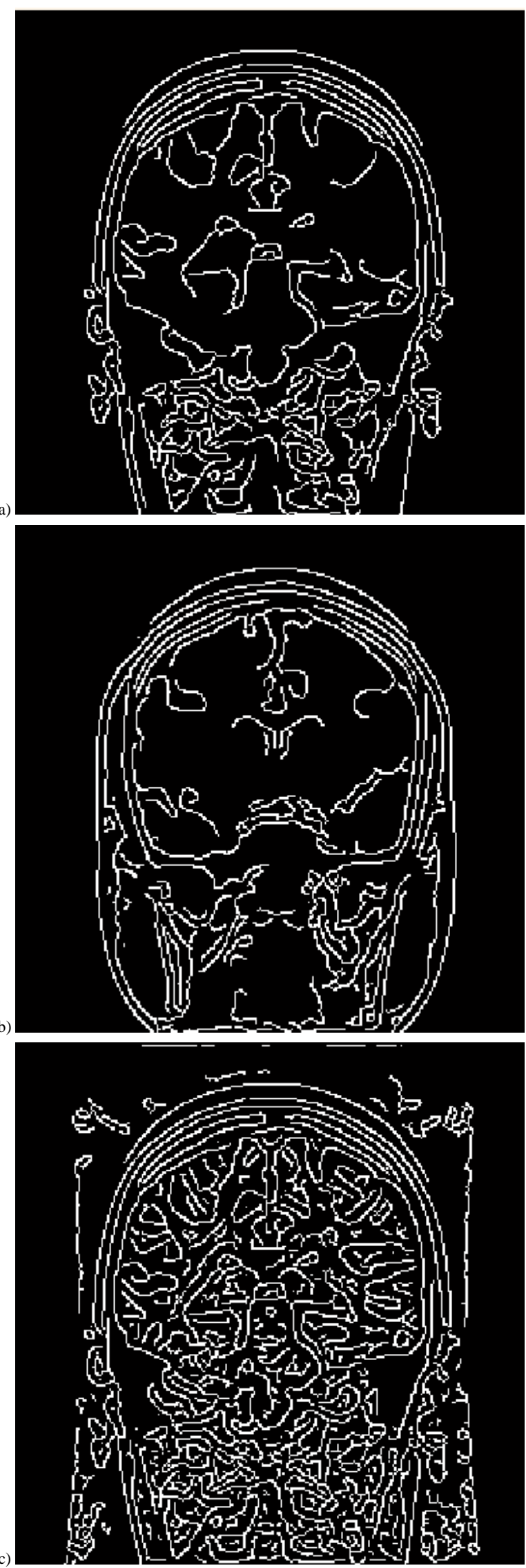

Fig. 3. Segmentation by edge detection: images with given parameters and masks (a) Threshold: 0.16 Prewitt, (b) 0.16 Sobel, (c) 0.02 Roberts
Parameters used during segmentation by region growth give the effects visible in Figure 4. They show the gray matter of brain (Figure 4a) and the white matter of brain along with the pons (Figure 4b).The hemispheres of human brain are surrounded by a gray matter that forms a cortex; there is a white matter within cortex that also contains the endbrain nucleior or subcortical nuclei.

Segmentation methods carried good results in the case of T1-dependent images. It was observed that reducing the (threshold) coefficient with selected mask causes detection of more edges. The optimal range was $0.16-0.2$. It allows showing the main edges in the image for each of the selected masks. In the event, where it is important to show more details, one should reduce the threshold value until a satisfactory result is obtained. The Canna mask gives a more satisfying segmentation effect comparing to the Sobel mask. Even the low value of the coefficient does not detect the noise in the image. For the same value of the coefficient it finds better mainly the edges in the image.
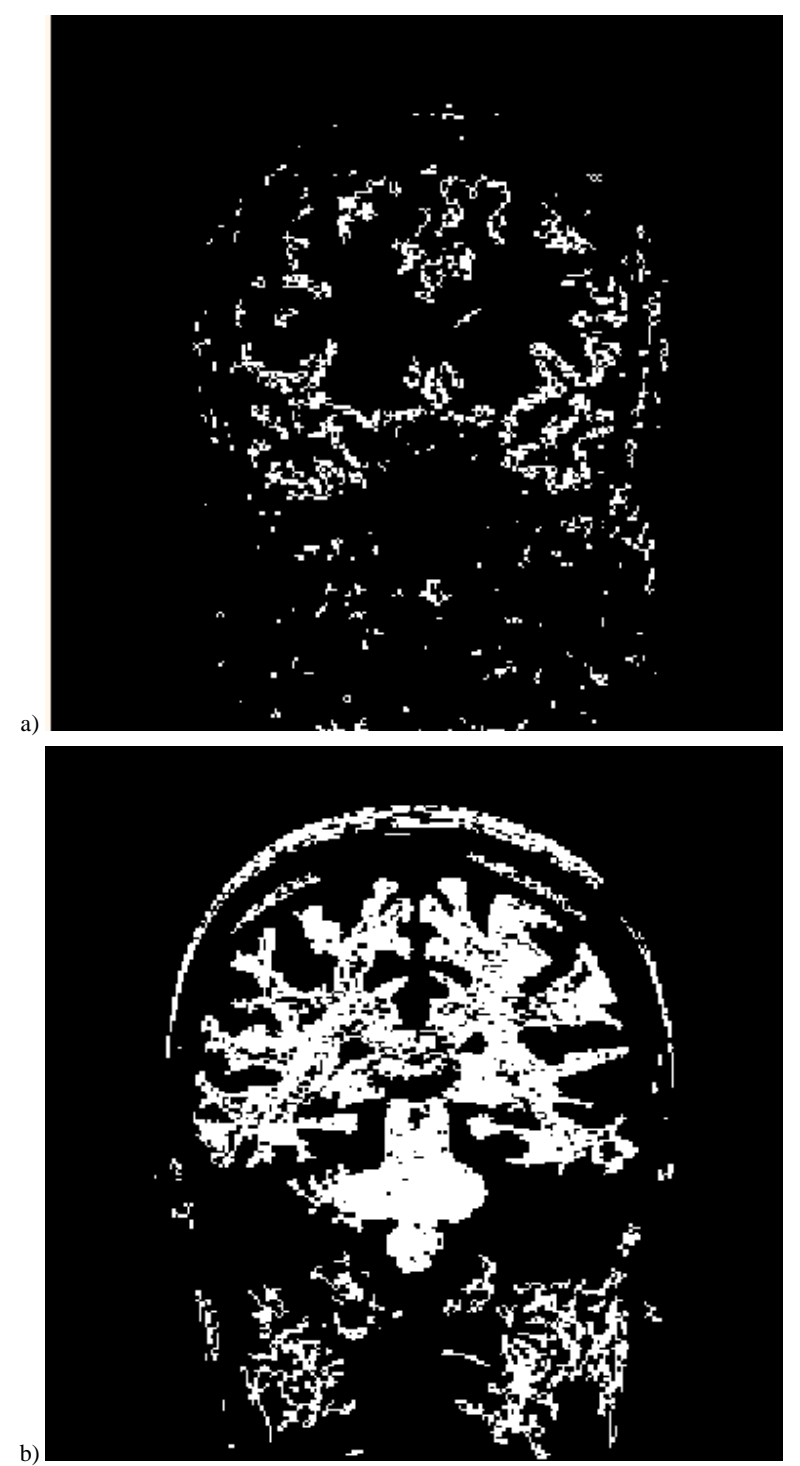

Fig. 4. Segmentation by region growth: images with given parameters Threshold/range:(a) 60/3,(b) 80/10

\section{Conclusions}

Each of the selected segmentation methods gives different effects for areas showing different anatomical structures. Using correctly selected algorithms allows to obtain correct segmentation of individual tissues. An effective type of segmentation is considered to be one that allows to distinguish a larger number of relevant elements. The segmentation methods 
presented in the article allow for different efficiencies. Its measure is the time of performing the operation, the complexity of the algorithm and the ability to recognize anatomical structures in the segmented images.

Analyzing the effectiveness of segmentation methods presented in the article, it can be concluded that the advantage of segmentation of the brain structures by the region's growth method is the high correctness of pixel assignment of features common to one region. The simplicity of the algorithm and the flexibility of parameter selection are also important Segmentation by region for complex images tends to create a large number of small areas. However, it allows to distinguish small anatomical structures, which are many in the human brain.

Edge segmentation with the use of Prewitt mask revealed that it is an effective tool. Specifies the size and orientation of the edges in human brain MRI images. The Sobel operator performs the averaging operation of the lead, making it less sensitive to image distortions than Robert's mask, and smoothing it better than Prewitt mask.

Many problems related to the efficiency of segmentation of medical images have not yet been resolved. Research is ongoing on more precise segmentation of anatomical elements, especially the smallest ones, such as blood vessels. The search for new segmentation algorithms is an important research challenge in field of computer image analysis. In future studies, the effectiveness analysis may be subjected to segmented structures derived from other types of imaging, eg USG or CT, and visualize them in $3 \mathrm{D}$.

\section{Bibliography}

[1] Avrunin O. G., Tymkovych M. Y., Moskovko S. P., Romanyuk S. O. Kotyra A., Smailova S.: Using a priori data for segmentation anatomica structures of the brain. Przegląd Elektrotechniczny 93/2017, 102-105.

[2] Bellon O. R., Silva L.: New improvements to range image segmentation by edge detection. IEEE Signal Processing Letters 9/2002, 43-45.

[3] Bernstein M. A., King K. F., Xiadhong J. Z.: Handbook of MRI pulse sequences. Amsterdam. Elsevier, 2004.

[4] Boskovitz V., Guterman H. An adaptive neuro-fuzzy system for automatic image segmentation and edge detection. IEEE Transactions on Fuzzy Systems 10/2002, 247-262.

[5] Hidayatullah R. R., Sigit R., Wasista S.: Segmentation of head CT-scan to calculate percentage of brain hemorrhage volume. Knowledge Creation and Intelligent Computing (IES-KCIC), IEEE, 2017, [DOI: 10.1109/KCIC.2017.8228603].
[6] Kaganami H. G., Beiji Z.: Region-Based Segmentation versus Edge Detection. Intelligent Information Hiding and Multimedia Signal Processing IIH-MSP'09. Fifth International Conference, 2009.

[7] Rebouças E. S., Braga A. M., Sarmento R. M.: Level Set Based on Brain Radiological Densities for Stroke Segmentation in CT Images. Computer-Based Medical Systems (CBMS), IEEE 2017 [DOI: 10.1109/CBMS.2017.172]

[8] Sharma N., Aggarwal L. M.: Automated medical image segmentation techniques. J. Med. Phys. 35/2010, 3-14.

[9] Suri J. S., Setarehdan S. K., Singh S.: Advanced Algorithmic Approaches to Medical Image Segmentation. Springer, 2002.

[10] Tadeusiewicz R., Korohoda P.: Komputerowa analiza i przetwarzanie obrazów. Wydawnictwo Postepu Telekomunikacji, Kraków 1997.

[11] Tadeusiewicz R., Śmietański J.: Pozyskiwanie obrazów medycznych oraz ich przetwarzanie, analiza, automatyczne rozpoznawanie i diagnostyczna interpretacja. Wydawnictwo Studenckiego Towarzystwa Naukowego, Kraków 2011

[12] Ulagamuthalvi V., Kulanthaivel G.: An novel approach for segmentation using brain images. International Conference on Control, Instrumentation, Communication and Computational Technologies (ICCICCT ), IEEE, 2017.

[13] Wróbel Z., Koprowski R.: Praktyka przetwarzania obrazów z zadaniami w programie Matlab. Akademicka Oficyna Wydawnicza EXIT, Warszawa 2012.

[14] Yahiaoui A. F. Z., Bessaid A.: Segmentation of ischemic stroke area from CT brain images, Signal, Image, Video and Communications (ISIVC), IEEE 2017 [DOI: 10.1109/ISIVC.2016.7893954].

\section{M.Sc. Róża Dzierżak \\ e-mail: r.dzierzak@pollub.pl}

Ph.D. student at the Electrical Engineering and Computer Science Faculty. Assistant in the Institute of Electronics and Information Technology of Lublin University of Technology. Recent graduate Biomedical Engineering and Computer Science. Her research interests include medical image processing.

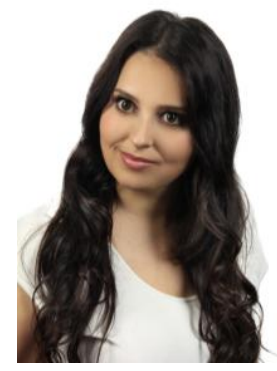

\section{M.Sc. Magdalena Michalska}

e-mail: magdalena.michalska@pollub.edu.pl

$\mathrm{Ph} . \mathrm{D}$. student at the department of Electronics and Information Technology, Lublin University of Technology. Recent graduate Biomedical Engineering and Electronic at Warsaw University of Technology.

Research field covers wide variety of 3D modeling, medical image processing, spectrophotometry.

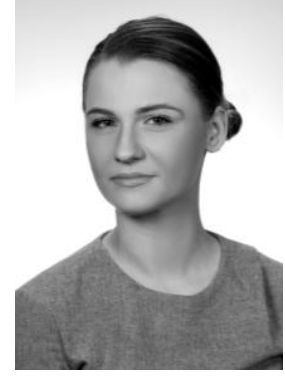

otrzymano/received: $24.04 .2018 \quad$ przyjęto do druku/accepted: 11.05 .2018 